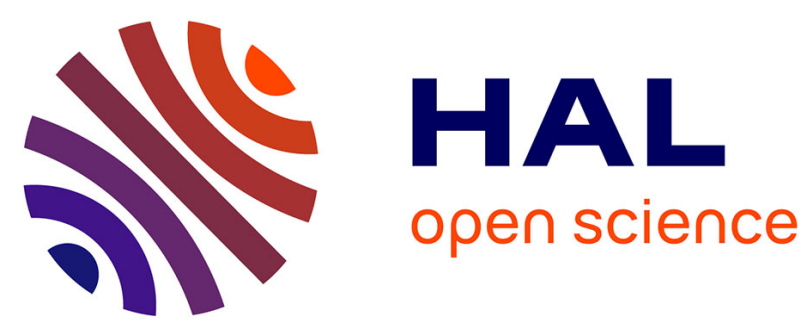

\title{
PRESSURE INDUCED PHASES TRANSITIONS IN GaP: AN X RAY ABSORPTION SPECTROSCOPY INVESTIGATION
}

\author{
J. P. Itie, A. Polian, C Jauberthie-Carillon, E Dartgge, A Fontaine, H \\ Tolentino, G Tourillon
}

\section{To cite this version:}

J. P. Itie, A. Polian, C Jauberthie-Carillon, E Dartgge, A Fontaine, et al.. PRESSURE INDUCED PHASES TRANSITIONS IN GaP: AN X RAY ABSORPTION SPECTROSCOPY INVESTIGATION. Physica B: Condensed Matter, 1989. hal-03059437

\section{HAL Id: hal-03059437 https://hal.science/hal-03059437}

Submitted on 12 Dec 2020

HAL is a multi-disciplinary open access archive for the deposit and dissemination of scientific research documents, whether they are published or not. The documents may come from teaching and research institutions in France or abroad, or from public or private research centers.
L'archive ouverte pluridisciplinaire HAL, est destinée au dépôt et à la diffusion de documents scientifiques de niveau recherche, publiés ou non, émanant des établissements d'enseignement et de recherche français ou étrangers, des laboratoires publics ou privés. 


\title{
PRESSURE INDUCED PHASES TRANSITIONS IN GaP: AN $X$ RAY ABSORPTION SPECTROSCOPY INVESTIGATION
}

\author{
J.P.Itie', A.Polian', C.Jauberthie-Carillon', E.Dartyge ${ }^{2}$, \\ A. Fontaine ${ }^{2}$, H. Tolentino $0^{2}$ G. Tourillon ${ }^{2}$. \\ 1: Physique des Mllieux Condensés, Université P\&M Curie, T13 E4, \\ 4 place Jussleu, 75252 PARIS Cedex05, France \\ 2: LURE, BAT 209D, Université Paris-Sud,91405 ORSAY Cedex, \\ France
}

Under high pressure, GaP exhibits a phase transition near $25 \mathrm{GPa}$, determıneo by optical measurements $(1,2)$ and $X$ ray diffraction $(3,4)$. When pressure is released, according to $X$ ray diffraction, the transition is reversible, although the diffraction peaks are weaker. But the sample remains black and optical properties of the initlal phase are no longer observed.

We have periormed an $X$ ray absorption spectroscopy experiment, at the Ga $K$ edge, on GaP up to $36 \mathrm{GPa}$, using the energy dispersive mode(5).

Finely powdered GaP has been loaded in a classical diamond anvil cell with silicone oil as pressure transmitting medium. A ruby chip was added to measure the pressure. The sample size was about $250 \mu \mathrm{m}$ in diameter and $30 \mu \mathrm{m}$ in thickness. Due to the optimized shape of the Si crystal(6), the energy range has been extended up to $400 \mathrm{eV}$.

The zincblende phase of GaP remains stable up to $23 \mathrm{GPa}$. In figure 1 , at 11.5 $\mathrm{GPa}$, a shift of the XANES to high energy is observed. Such a behaviour is consistent with a decrease of the Ga-P bond length (fig 2 ). The variation of the Ga-P distance has been determined using the classical EXAFS fitting procedure. The backscattering amplitude and the phase shift was odtained from the zero pressure data. The results have been fitted to a Murnaghan equation of state with $B=88.1 \mathrm{GPa}$ and $B^{\prime}=4.5$. The value of the bulk modulus is in good agreement with ultrasonic data $(B=87.5 \mathrm{GPa})$.

At $26 \mathrm{GPa}$, the spectrum is perturbated by the mixing of two phases. At 36 $\mathrm{GPa}$, the transition is complete and the near edge spectrum is different from 
the low pressure one (figl). In figure 2,c, an increase of the first neighbour distance is observed, indicating a change in the neighbour configuration. A two shells adjustement, with $4 P$ and $2 \mathrm{Ga}$ gives $2.41 \mathrm{~A}$ and $2.44 \mathrm{~A}$ for $\mathrm{Ga}-\mathrm{P}$ and Ga-Ga distances respectively. These results are in good agreement with the $\beta$ tin structure proposed $(3,4)$ for the GaP high pressure phase.

When pressure is released, the near edge spectrum differs from both high and low pressure spectra(figl). It looks like amorphous Gap. The lack of second neighbours in figure 2,d, leads to the same conclusion: a large amount of the sample is amorphous. The existence of a zincblende diffraction pattern(2) indicates that a small part of the sample reverts to the initial phase. A partial amorphisation accounts for the weakening of the diffracted lines and the change in optical properties.

I J.P.Pinceaux, J.M.Besson, A.Rimsky and G. Weil, in High Pressure Science and Technology vol 1 , ed B.Vodar and P. Marteau, Pergamon press, Oxford (1980) p 241

2) C. Jauberthie-Carillon and C.Gulllemin unpublished

3)M. Baublitz and A.L.Ruoff, J of Appl. Phys. 53, 6179 (1982)

4)J.Z. Hu, D.R.Black and I.L.Spain, Sol. Stat. Comm. 51, 285 (1984)

5) E.Dartyge, C.Depautex, J.M.Dubuisson, A.Fontaine, A.Jucha and G. Tourillon, N.I.M. A246, 452 (1986)

6) H. Tolentino, E.Dartyge, A.Fontaine and G.Tourillon, J. Appl. Cryst. 21, IS (1988)

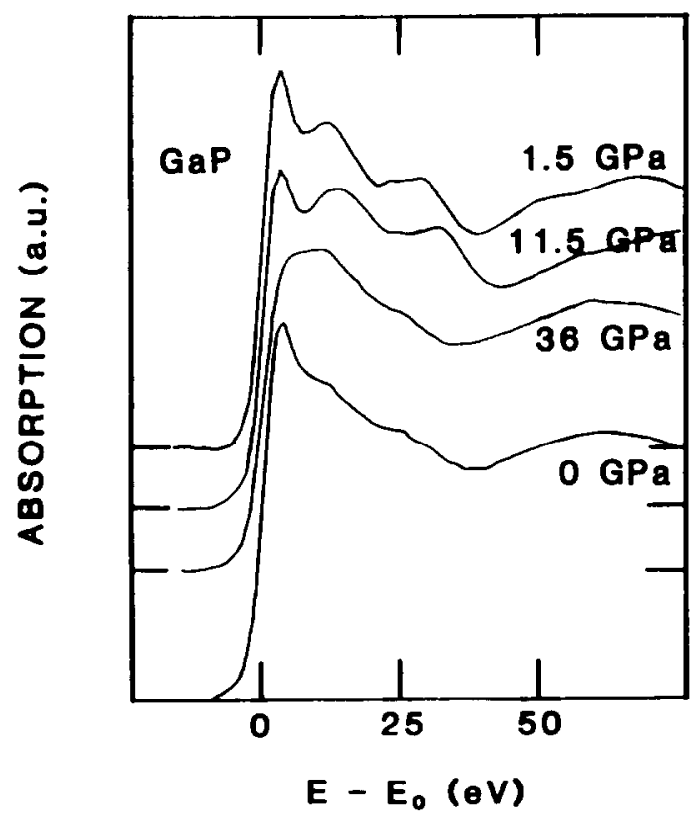

fig 1:XANES of GaP at different pressures

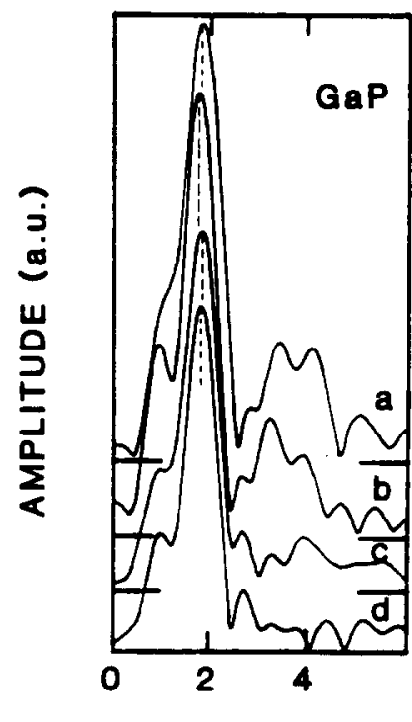

\section{DISTANCE (A)}

fig2:Fourier transform of GaP EXAFS a)1.2 GPa, b)11. $5 \mathrm{GPa}, \mathrm{c}) 36 \mathrm{GPa}$ d) $0 \mathrm{GPa}$ after releasing pressure 